DOI https://doi.org/10.30525/978-9934-588-81-5-2.32

\title{
CHANGES OF HEMATOLOGICAL AND HEMODYNAMIC INDICATORS OF RATS AFTER SINGLE INTRATRACHEAL INTRODUCTION OF LEAD NANOPARTICLES OF DIFFERENT SIZE
}

\author{
Gubar I. V. \\ PhD Student \\ Bogomolets National Medical University, \\ Researcher
}

State Institution «Kundiiev Institute of Occupational Health of the National Academy of Medical Sciences of Ukraine» Assistant Professor at the Fundamental Medicine Department Educational and Scientific Center "Institute of Biology and Medicine» of Taras Shevchenko National University of Kyiv

Yavorovsky O.P. Doctor of Medical Sciences, Professor, Head of Hygiene and Ecology Department № 2 Bogomolets National Medical University

Kaminsky R. F. Candidate of Medical Sciences, Associate Professor, Associate Professor at the Descriptive and Clinical Anatomy Department Bogomolets National Medical University

Chaikovsky Yu. B.

Doctor of Medical Sciences, Professor, Head of Histology and Embryology Department

Bogomolets National Medical University

Sokurenko L. M.

Doctor of Medical Sciences, Professor,

Professor at the Histology and Embryology Department

Bogomolets National Medical University,

Educational and Scientific Center «Institute of Biology and Medicine» of Taras Shevchenko National University of Kyiv Kyiv, Ukraine

Introduction. New physicochemical properties of engineered nanoparticles (NPs) make them very attractive for use in industrial and biomedical 
purposes. The manufacture and use of nanotechnology products has reached industrial scale and continues to grow worldwide, raising concerns about the potential adverse health effects for both nanoindustry workers and nanoproduct consumers $[1 ; 2]$.

Nanoparticles entering the air of the working area can contribute to the cardiopulmonary effects observed in workers [3] and were associated with the occupational exposure to the studied NPs.

The morbidity rate of workers can be determined both by the toxicity of the studied substances and the ability of their ultrafine particles to deeply penetrate into body tissues. It has been experimentally established [4] that the cardiotoxic effect of NPs depends on both the toxicity of the compounds and the size of their nanoparticles. Thus, the commercial benefits of nanomaterials should not outweigh the potential adverse effects on human health and the environment associated with the effects of exposure to them in the occupational and consumer environment [5].

To date, the mechanisms underlying nanotoxicity, in particular those of the lead NPs as one of the most common and highly toxic metals, have not been fully studied. This necessitates comprehensive toxicological studies of nanosized compounds.

The aim of the work was to study hematological parameters of peripheral blood and hemodynamics of rats under the action of lead sulfide NPs of different sizes in comparison with the ionic form (lead nitrate) on an experimental model of single intratracheal intoxication.

Materials and methods. Lead compounds in nanoform were used: lead sulfide NPs (PbS NPs) with an average size of 26-34 nm and 50-80 nm and in ionic form: lead nitrate $\left(\mathrm{Pb}\left(\mathrm{NO}_{3}\right)_{2}\right)$, which is well soluble in water. Lead sulfide NPs were obtained by chemical synthesis using stabilizer of sodium polyphosphate $\left(\mathrm{NaPO}_{3}\right)_{\mathrm{n}}$.

The study was conducted on adult male rats weighing 250-280 g. The animals were kept in vivarium conditions on a standardized diet with free access to drinking tap water. Rats were divided into 3 experimental groups and control: experimental group I was administered PbS NPs of 26-34 nm in size, group $2-\mathrm{PbS} \mathrm{NPs}$ with a size of $50-80 \mathrm{~nm}$, group $3-\mathrm{Pb}\left(\mathrm{NO}_{3}\right)_{2}$; the control group of animals was injected with normal saline. The test substances were administered intratracheally once at a dose of lead $5 \times 10^{-3}$ Mol/l. Toxic effects were assessed 12 days after exposure.

At the end of the experimental period rheographic parameters were recorded on the hardware-software complex DX-NT Regina-2002 using the method of bipolar rheovasography under light ether anesthesia. The following hemodynamic coefficients were recorded: maximum rate of accelerated 
filling (MRAF), mean rate of slow filling (MRSF), dichroic index (DI) and diastolic index (DSI).

To study hematological parameters, blood was drawn after decapitation. The clinical blood count with differential was carried out on the hematologic analyzer ABX MICROS 60 according to the manufacturer's instructions.

All manipulations with animals were performed in accordance with the provisions of the «European Convention for the Protection of Vertebrate Animals, Used for Experimental and Other Scientific Purposes» (Strasbourg, 1985) and approved by the Bioethics Committee of the NAS of Ukraine. The experiment plan was approved by the Bioethics Commission of State Institution «Kundiiev Institute of Occupational Health of the National Academy of Medical Sciences of Ukraine» (Minutes № 5, session of bioethics commission from 23.11.2017).

Data are presented as medians with smaller and larger quartiles (M[Q1Q3]), since normality was not proven. The difference was considered statistically significant at $\mathrm{P}<0.05$.

Research results. A single intratracheal administration of colloidal solutions with lead particle sizes of both micro and nanoscale to experimental rats resulted in changes in hematological parameters. There was a decrease in hemoglobin concentration in the peripheral blood of experimental animals.under the action of low-size lead NPs This may indicate a violation of the processes of heme synthesis, though this change was not statistically significant. Statistically significant decrease in the erythrocytes count in the peripheral blood of rats was registered in this experimental group. This indicates the suppression of erythropoiesis under the action of PbS NPs of 26-34 nm. An increase in the leukocyte count in the blood of the experimental groups animals was observed in comparison with the control group, but it was statistically significant only under the action of lead nitrate. The relative count of lymphocytes decreased statistically significantly in the peripheral blood of animals after administration of smaller PbS NPs and lead nitrate. An increase in the absolute number of granulocytes was observed in the blood of rats of all experimental groups. These changes were not statistically significant. A statistically significant increase in the relative count of granulocytes was recorded in groups of animals exposed to smaller PbS NPs and lead nitrate in ionic form. The hematocrit was statistically significantly lower relative to the control in the blood of animals after exposure to a lower PbS NPs. There was an increase in the control of platelet counts in the blood of rats exposed to $\mathrm{Pb}\left(\mathrm{NO}_{3}\right)_{2}$ in ionic form, but this change was not statistically significant. Single intratracheal administration of colloidal solutions of lead ( $\mathrm{PbS}$ of $26-34 \mathrm{~nm}$; $\mathrm{PbS}$ of $50-80 \mathrm{~nm}$ ) and 
$\mathrm{Pb}\left(\mathrm{NO}_{3}\right)_{2}$ in ionic form caused changes in tonic hemodynamic parameters: a more significant increase in DI (reflects the state of the tone of small caliber vessels of the initial part of the microcirculatory bed: arterioles and precapillaries) and DSI (reflects the state of vascular tone of the final part of the microcirculatory bed: postcapillaries, venules, veins) relative to control values. Wherein changes in DI under $\mathrm{Pb}\left(\mathrm{NO}_{3}\right)_{2}$ administration were statistically significant relative to control values.

The increase in hemodynamic velocity parameters: MRAF (reflects the rate of blood supply of large arterial vessels and the state of tone of their walls) and MSSF (reflects the rate of blood supply of arterial vessels of medium and small caliber and the state of tone of their walls) were more significant in experimental animals. This was the case under $\mathrm{Pb}\left(\mathrm{NO}_{3}\right)_{2}$ administration, although there were no statistically significant differences.

Conclusions

1. It was found that a single intratracheal administration of colloidal solutions of lead sulfide $\mathrm{NPs}$ and $\mathrm{Pb}\left(\mathrm{NO}_{3}\right)_{2}$ in ionic form to experimental rats caused changes in the peripheral blood (decreased hemoglobin, erythrocytes and hematocrit), which may indicate a disruption of the heme synthesis process and suppression of erythropoiesis. Increased leukocyte count, decreased relative lymphocyte count, as well as increased relative granulocyte count may be a sign of the development of an inflammatory process in the organism of experimental rats.

2. Signs of cardiovasotoxic action of lead NPs include changes in the peripheral hemodynamics, which indicate an increase in the tone of small vessels, the tone of the initial part of the microcirculatory bed: arterioles and precapillaries, dystrophic changes in the myocardium. The influence of lead nitrate in ionic form had led to an increase in vascular tone of the terminal part of the microcirculatory bed: postcapillaries, venules, veins, increase in the rate of blood supply of large arterial vessels and the state of tone of their walls and blood flow rate of arterial vessels of medium and small caliber and tone of their walls.

\section{References:}

1. Porcari A., Borsella E., Benighaus C., Grieger Kh., Isigonis P., Chakravarty S., Kines P., Jensen K. A. From risk perception to risk governance in nanotechnology: a multi-stakeholder study. J Nanopart Res 2019; 21: 245 .

2. Khan I., Saeed K., Khan I. Nanoparticles: Properties, applications and toxicities. Arabian Journal of Chemistry, 2019; 12(7): 908-931. https://doi.org/10.1016/j.arabjc.2017.05.011 
3. Zhao L, Zhu Y, Chen Z, Xu H, Zhou J, Tang S, Xu Z, Kong F, Li X, Zhang Y, Li X, Zhang J, Jia G. Cardiopulmonary effects induced by occupational exposure to titanium dioxide nanoparticles. Nanotoxicology. 2018; 12(2):169-184

4. Bostan H.B., Rezaee R., Valokala M.G., Tsarouhas K., Golokhvast K., Tsatsakis A.M., Karimi G. Cardiotoxicity of nanoparticles. Life Sciences. 2016; 165: 91-99. DOI: 10.1016/j.lfs.2016.09.017

5. Warheit D.B. Hazard and risk assessment strategies for nanoparticle exposures: how far have we come in the past 10 years? F1000Res. 2018; 7:376. https:// doi.org/10.12688/f1000research.12691.1.

DOI https://doi.org/10.30525/978-9934-588-81-5-2.33

\title{
ОЦНКА ЗАПАЛЬНОГО ПРОЦЕСУ \\ ПРИ ЕКСПЕРИМЕНТАЛЬНОМУ ВАГІНІТІ ТА ЗА УМОВ КОРЕКЦІЇ ВАГІНАЛЬНИМИ СУППОЗИТОРІЯМИ «КЛІМЕДЕКС» ТА «МЕЛАНІЗОЛ»
}

\author{
Должикова О. В. \\ кандидат фармачевтичних наук, \\ дочент кафедри клінічної лабораторної діагностики \\ Наиіональний фармачевтичний університет \\ Срьоменко Р. Ф. \\ доктор біологічних наук, \\ професор кафедри клінічної лабораторної діагностики \\ Наиіональний фармацевтичний університет \\ Козар В. В. \\ кандидат медичних наук, \\ доцент кафедри клінічної лабораторної діагностики \\ Національний фармачевтичний університет \\ м. Харків, Україна
}

Лікування вагінітів визначається адекватною та своєчасною антимікробною терапією. Оскільки дуже часто первинний перебіг запальних захворювань геніталій має мінімальні клінічні прояви та тенденцію до хронізації процесу, стандартна антибіотикотерапія не завжди в таких випадках $є$ ефективною, що обумовлено багатьма чинниками, як то розвиток стійкості мікроорганізмів до антибіотиків, алергізація в результаті тривалого застосування антибіотиків тощо. Тому продов- 